Note

(Received September 3, 1986)

\title{
CHANGES IN FINE STRUCTURE AND DYEING BEHAVIOR OF POLY(ETHYLENE TEREPHTHALATE) DURING CONTINUOUS HIGH PRESSURE STEAMING
}

\author{
By Liyuan Han, Tomiji Wakida and Toru Takagishi ${ }^{\bullet}$ \\ (Faculty of Engineering and Design, Kyoto Institute of Technology, \\ Matsugasaki, Sakyo-ku, Kyoto 606, Japan) \\ -1 (Department of Applied Chemistry, College of Engineering, \\ University of Osaka Prefecture, Sakai, Osaka 591, Japan)
}

\begin{abstract}
Poly(ethylene terephthalate) (PET) fiber and fabric were treated with a continuous high pressure steaming machine. The degrees of fixations of C. I. Disperse Violet 1 and Yellow 7 for the fabrics treated with high pressure steam, superheated steam, and dry heat were compared. Also the morphological changes of the fibers caused by the high pressure steaming were investigated by measurements of X-ray diffraction pattern, crystallite size, density, and saturation dye-uptake value in comparison with those induced by the superheated steaming and the dry heat treatment. The degree of fixation was found to increase in the following order: dry heat treatment, superheated steaming, high pressure steaming. Furthermore, the high pressure steaming enhanced the crystallinity and crystallite size more largely than the dry heat treatment or the superheated steaming, whereas the saturation dye-uptake value was unchanged by these steaming and heat treatment.
\end{abstract}

\section{INTRODUCTION}

In textile dyeing and finishing there are many processings such as pad-steam dyeing, development of printing, and setting to utilize steam. The nature of steam such as superheated steam and high pressure steam affects the quality of dyeing and finishing products.

Continuous steaming so far used is restricted to superheated steaming because only batch system permits high pressure steaming. Recently Sando Iron Works Co. has manufactured a continuous high pressure steaming machine in which temperature can be raised to $150^{\circ} \mathrm{C}$. In this investigation the effect of water vapor in high pressure steam on the fixation of disperse dye and the fine structure of PET was examined using the continuous high pressure steamer which is in practical operation.

\section{EXPERIMENTAL}

\subsection{Materials}

Poly(ethylene terephthalate) (PET) taffeta and fiber ( $75 \mathrm{~d} / 24$ filaments) were desized and scoured. The disperse dyes employed were C. I. Disperse Violet 1 and Yellow 7.

\subsection{Padding and steaming}

The fixations of C. I. Disperse Violet 1 and Yellow 7 on the PET fabrics were made by steaming or heat treatment.

PET taffeta was padded with dye solution containing $1 \%$ (o.w.f.) dye and $1 \%$ (o.w.f.) sodium alginate. The pickup of padding solution was controlled to $50 \%$ and then dried at $100^{\circ} \mathrm{C}$.

The high pressure steaming was carried out at $130^{\circ}, 140^{\circ}$, and $150^{\circ} \mathrm{C}$ for $1 \mathrm{~min}$ using a continuous high pressure steaming machine manufactured by Sando Iron Works Co. (Figure 1). The superheated steaming and the dry heat treatment were made by a Tsuji univapo experiment machine. After steaming the reduction cleaning for the dyed sample was done. The color depth (K/S value) was obtained from reflectance measured by a Hitachi 307 spectrophotometer. 


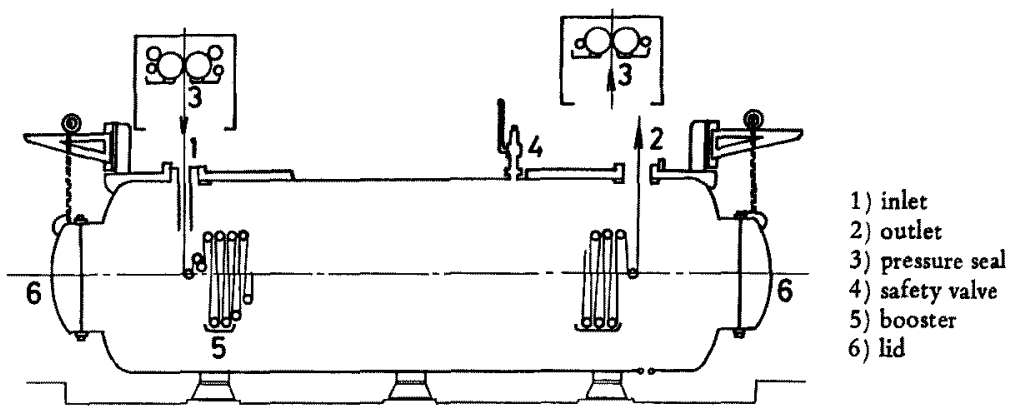

Fig. 1. Continuous high pressure steamer

2.3 X-ray diffraction pattern, crystallite size, and crystallinity

X-ray diffraction patterns were obtained using the same method as that described in a previous article. ${ }^{1)}$ The crystallite size of $(010),(\overline{1} 10)$, and (100) planes was calculated by Scherrer's equation. The degree of crystallinity was determined by the density measurements which were made using a density gradient column of carbon tetrachloride and toluene,

\subsection{Dyeing}

The PET fibers pretreated with high pressure steam, superheated steam, and dry heat were dyed with C. 1 . Disperse Violet 1 at $120^{\circ} \mathrm{C}$ for $5 \mathrm{hr}$ in a water dyebath with a liquor ratio of 800 to 1 using a Tumblet high pressure dyeing apparatus. The concentration of dyebath was $2 \mathrm{~g} / \mathrm{l}$. After dyeing the dyed fibers were rinsed with acetone at room temperature for $10 \mathrm{sec}$ to remove surfaceheld dye. Then the samples were extracted with dimethylformamide at $100^{\circ} \mathrm{C}$ and the content of dye was determined spectrophotometrically.

\section{RESULTS AND DISCUSSION}

3.1 Fixation of disperse dye on PET fabric by high pressure steaming, superheated steaming, and dry heat treatment

The color depth (K/S value) of PET fabric treated with high pressure steam, superheated steam, or dry heat is summarized in Table 1 . The $\mathrm{K} / \mathrm{S}$ value increases with an increase in the content of water vapor in the treated medium: dry heat < superheated steam < high pressure steam. It is well known that water vapor in the medium condenses on the surface of fiber at the initial stage of steaming and the condensed water solubilizes the disperse dye padded on the fiber surface. Since high pressure steam contains much more water vapor than superheated steam, the $K / S$ value, which is proportional to the amount of fixed dye,

Table 1. K/S value, crystallinity, crystallite size, and saturation dye-uptake value of PET treated with high pressure steam, superheated steam, and dry heat

\begin{tabular}{|c|c|c|c|c|c|c|c|c|}
\hline & \multirow{2}{*}{$\begin{array}{l}\text { Temp. } \\
\left({ }^{\circ} \mathrm{C}\right)\end{array}$} & \multicolumn{2}{|c|}{$\mathrm{K} / \mathrm{S}$ value } & \multirow{2}{*}{$\begin{array}{c}\text { Crystallinity } \\
(\%)\end{array}$} & \multicolumn{3}{|c|}{$\begin{array}{l}\text { Crystallite } \\
\text { size (A) }\end{array}$} & \multirow{2}{*}{$\begin{array}{l}\text { Saturation } \\
\text { dye-uptake } \\
\text { value a) }\end{array}$} \\
\hline & & Violet 1 & Yellow 7 & & $(010)$ & $(\overline{1} 10)$ & $(100)$ & \\
\hline Untreated & & & & 32.2 & 22.2 & 21.5 & 21.9 & 1.17 \\
\hline High pressure & 130 & 2.48 & 3.07 & 41.5 & 38.1 & 30.2 & 36.8 & 1.16 \\
\hline \multirow[t]{2}{*}{ steam } & 140 & 2.52 & 3.68 & 43.4 & 42.1 & 35.3 & 36.8 & 1.14 \\
\hline & 150 & 2.61 & 4.20 & 45.2 & 45.6 & 39.7 & 41.5 & 1.13 \\
\hline Superheated & 130 & 0.84 & 2.50 & 39.9 & 34.6 & 29.1 & 31.1 & 1.19 \\
\hline \multirow[t]{2}{*}{ steam } & 140 & 1.23 & 2.77 & 41.5 & 36.5 & 31.1 & 32.4 & 1.19 \\
\hline & 150 & 1.60 & 2.94 & 42.5 & 40.1 & 32.6 & 33.1 & 1.17 \\
\hline \multirow[t]{3}{*}{ Dry heat } & 130 & 0.37 & 1.38 & 38.2 & 31.6 & 25.1 & 28.9 & 1.16 \\
\hline & 140 & 0.98 & 2.57 & 38.8 & 32.8 & 27.1 & 30.4 & 1.16 \\
\hline & 150 & 1.33 & 2.91 & 42.3 & 36.0 & 31.9 & 31.9 & 1.15 \\
\hline
\end{tabular}

a) C. I. Disperse Violet $1,10^{-4} \mathrm{~mol} / \mathrm{g}$ fiber 
for the high pressure steaming is larger than that for the superheated steaming at a given steaming temperature. Dry heat contains little water vapor and hence its $\mathrm{K} / \mathrm{S}$ value becomes the smallest. Furthermore, in all cases the $\mathrm{K} / \mathrm{S}$ value increases with increasing temperature of the medium.

3.2 X-ray diffraction pattern, crystallite size, and crystallinity

It is expected that the water condensed on the fiber during steaming leads to morphological changes of fiber structure. The X-ray photographs of PET fibers treated with high pressure steam, superheated steam, and dry heat are shown in Figure 2. The intensity of reflection of (010), $(\overline{1} 10)$, and (100) planes increases in the order: dry heat $<$ superheated steam $<$ high pressure steam. This result suggests that the high pressure steaming induces the crystallite growth more significantly than the dry heat treatment or superheated steaming. In particular the pronounced crystallization of the polymer occurs in the case of the high pressure steaming at $150^{\circ} \mathrm{C}$.

The degree of crystallinity obtained from the density measurements and the crystallite size of (010), $(\overline{1} 10)$, and (100) planes are presented in Table 1 . The crystallinity and the crystallite size increase with increasing temperature. At a fixed temperature both crystallinity and crystallite size increased in the following order: dry heat treatment, superheated steaming, high pressure steaming. These observations correspond to those of $\mathrm{X}$-ray diffraction patterns demonstrated in Figure 2. From these results it is likely that the condensed water on the fiber plays a significant role in the crystallization of the fiber.
1

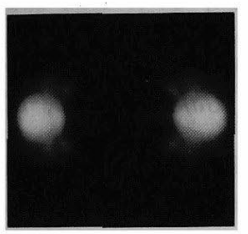

2

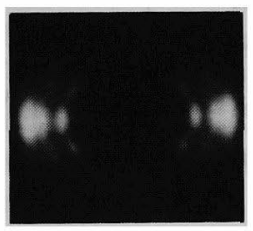

5

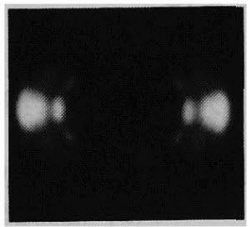

8

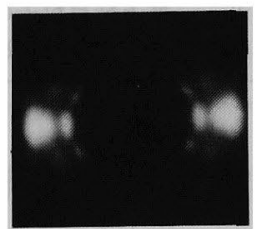

3

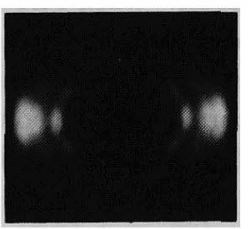

6

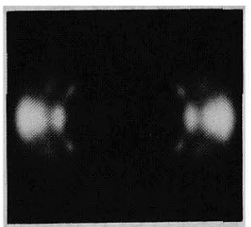

9

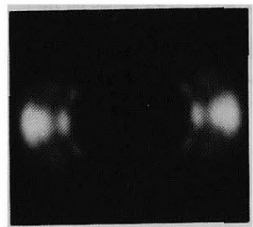

4

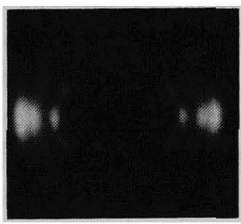

7

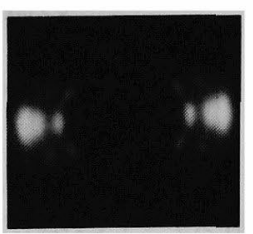

10

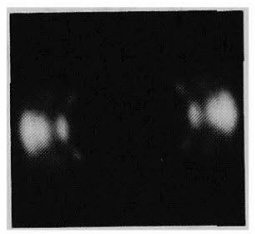

Fig. 2. X-ray diffraction patterns of PET fibers treated with high pressure steam, superheated steam, and dry heat
1) Untreated
2) High pressure steaming, $130^{\circ} \mathrm{C}$
3) High pressure steaming, $140^{\circ} \mathrm{C}$
4) High pressure steaming, $150^{\circ} \mathrm{C}$
5) Superheated steaming, $130^{\circ} \mathrm{C}$

6) Superheated steaming, $140^{\circ} \mathrm{C}$

7) Superheated steaming, $150^{\circ} \mathrm{C}$

8) Dry heat treatment, $130^{\circ} \mathrm{C}$

9) Dry heat treatment, $140^{\circ} \mathrm{C}$

10) Dry heat treatment, $150^{\circ} \mathrm{C}$ 


\subsection{Dyeability}

To gain an insight into the changes in amorphous regions by the steaming, the saturation dye-uptake values of PET fibers pretreated with high pressure steam, superheated steam, and dry heat were determined. The results obtained are also listed in Table 1. As can be seen in Table 1, the saturation dye-uptake value of the fiber treated with high pressure steam shows no appreciable difference in comparison with those treated with superheated steam and dry heat although the value of high pressure steaming at $150^{\circ} \mathrm{C}$ decreases slightly. The high pressure steaming causes to increase the crystallinity and crystallite size more largely than the other treatments but the saturation dye-uptake value is almost unchanged. It is likely that plasticization of the amorphous regions does not occur during the high pressure steaming. Water vapor induces the recrystallization of the fiber but does not influence appreciably the amorphous regions accessible to the dye molecule. When PET fibers were treated by prolonged superheated steaming, an increase in crystallinity and a decrease in saturation dye-uptake occurred simultaneously. ${ }^{2)}$ In previous articles ${ }^{1,3-8)}$ it was described that treatments of PET with strongly-interacting solvents such as dimethylformamide, butanol, benzyl alcohol, tetrachloroethylene, and tetrachloroethane lead to both crystallization and plasticization of the fiber, while water treatment exhibits small plasticizing effect.

\section{REFERENCES}

1) T. Takagishi, T. Wakida and N. Kuroki, Sen-i Gakkaishi, 34, T-536 (1978)

2) L. Han, T. Wakida and T. Takagishi, Textile Res. J., in press

3) H.-D. Weigmann, M. G. Scott, A. S. Ribnick and L. Rebenfeld, Textile Res. J., 46, 574 (1976)

4) H.-D. Weigmann, M. G. Scott, A. S. Ribnick and R. D. Matkowsky, Textile Res. J., 47, 745 (1977)

5) H.-D. Weigmann, M. G. Scott and A.S. Ribnick, Textile Res. J., 47, 761 (1977)

6) H.-D. Weigmann, M. G. Scott and A. S. Ribnick, Textile Res. J., 48, 4 (1978)

7) T. Wakida, T. Takagishi, G. J. Kim and N. Kuroki, Sen-i Gakkaishi, 39, T-87 (1983)

8) Y. J. Lim, M. Tahara, T. Takagishi, N. Kuroki and T. Wakida, Sen-i Gakkaishi, 40, T-216 (1984)

\section{連続高王スチーミングによるポリエチレンテレフタレート \\ の微細構造および染色性の変化}

$\begin{array}{ll}\text { 京都工芸緎維大学工芸学部 } & \text { 韓 } \text { 礼元, 脇田登美司 } \\ \text { 大阪府立大学工学部 } & \text { 高岸 徹 }\end{array}$

ポリエチレンテレフタレート䋞維およびタフタを連続 式高王スチーマで好理し, 分散染料 (C. I. Disperse Violet 1 およびYellow 7) に対する固着率を乾熱およ び過熱蒸気で姏理したものと比較した。さらに，高王ス チーミング, 過熱スチーミングおよび乾熱処理したポリ エチレンテレフタレート緎維の内部構造の変化を，X線
回折，結晶化度および飽和染着量によって調べた。固着 率は，乾熱処理く過熱スチーミングく高开スチーミング の順に增大した。また，過熱スチーミングおよび乾熱処 理の場合よりす，高王スチーミングの場合のはうが結晶化 度と結昆柆子の大きさは増大するが，飽和染着量にはは とんど差は認められなかった。 